\title{
The Effect of Corporate Governance Characteristics on Environmental Performance: The Case of Food and Beverage Sector
}

\author{
Grigoris Giannarakis ${ }^{1}$, Nikolaos Sariannidis ${ }^{2}$, George Konteos ${ }^{1}$ \\ ${ }^{1}$ Department of Business Administration, University of Western Macedonia, Grevena, Greece \\ ${ }^{2}$ Department of Accounting and Finance, University of Western Macedonia, Kozani, Greece \\ Email: ggiannarakis@uowm.gr
}

How to cite this paper: Giannarakis, G., Sariannidis, N. and Konteos, G. (2020). The Effect of Corporate Governance Characteristics on Environmental Performance: The Case of Food and Beverage Sector. Open Journal of Business and Management, 8, 1988-2005.

https://doi.org/10.4236/ojbm.2020.85122

Received: May 19, 2020

Accepted: August 29, 2020

Published: September 1, 2020

Copyright $\odot 2020$ by author(s) and Scientific Research Publishing Inc. This work is licensed under the Creative Commons Attribution International License (CC BY 4.0).

http://creativecommons.org/licenses/by/4.0/

\begin{abstract}
The purpose of this study is to investigate the effect of the main Corporate Governance (CG) characteristics on the corporate environmental performance. In addition, it focuses on global food companies as this sector is distinguished by specific characteristics. The sample of the study employs 174 food companies from the Thomson Reuters Global Food \& Beverages Price Return Index for 2017. The Environmental Score as calculated by Thomson Reuters is adopted in the proposed model as a proxy of corporate Environmental Performance (EP). A regression analysis is developed in order to investigate the Board Size, the Board Independence and the Board gender composition of Board of Directors (BoD) on EP. The results revealed that the size of the $\mathrm{BoD}$ and the presence of women directors on Board have a positive effect on environmental performance. The study assists corporate managers to implement the appropriate Board characteristics in order to enhance their $\mathrm{EP}$ and socially responsible investors to identify companies with higher level of EP. This study extends the scope of previous studies by investigating the food and beverage sector and understanding of CG characteristics on EP taking into account innovating index as a proxy of EP.
\end{abstract}

\section{Keywords}

Corporate Governance, Board of Directors, Environmental Performance

\section{Introduction}

The concept of Corporate Social Responsibility (CSR) increases its awareness among different corporate stakeholders, such as corporate managers, investors, consumers, academic community and suppliers (Galvão et al., 2019). The term 
of CSR means different things to different stakeholders and it is changing over time (Arlow \& Gannon, 1982; Kitchin, 2002; Jamali, 2008). Among the most well-known definitions of CSR is the one proposed by the Commission of European Communities (2001) in the Green paper stating that CSR “... means not only fulfilling legal expectations, but also going beyond compliance and investing 'more' into human capital, the environment and the relations with stakeholders". Undoubtedly, the environmental aspect is one of the most important aspects of CSR and it has attracted the interest of scientific community to investigate the main factors that affect the environmental performance and its relationships with other corporate aspects such as economic one (e.g. Clarkson et al., 2011; Naciti, 2019).

This study focuses on the effect of corporate governance characteristics and, mainly, on the characteristics of BoD on environmental performance. The concept of corporate governance is not precisely defined by academic literature (Wajeeh \& Muneeza, 2012). The Organization for Economic Co-operation and Development states that corporate governance is the system that a company is directed and controlled by defining the rights and the responsibilities of different parties of a company such as BoD, shareholders and managers (Organisation for Economic Co-operation and Development, 2004). More specifically, Campbell (2007) incorporated the role, function and structure of board of directors in making decisions. Due to recent corporate scandals such the ones of Enron and Worldcom, the BoD attracts the attention as it is considered accountable for (Alanazi, 2019).

As far as food and beverage companies and CSR are concerned, Wei et al. (2018) supported that consumers have an increased desire to select healthy foods and buy goods from companies that incorporate socially responsible initiatives in their business operations. In addition, Hartmann (2011) supported that the concept of CSR is of high relevance with this sector since it depends on natural, human and physical resources and the value chain of food sectors has specific characteristics as it is affected by different aspects such as the environmental and societal ones. Focusing on the food retailers, Environmental initiatives are on CSR agenda of food retailers leaders because companies have to take into account a number of environmental issues such as energy consumption, natural and chemical, use of packaging, waste disposal and emissions (Roberts, 2003; Jones et al., 2005). In the field of supply chain, companies related to food and beverage have developed environmental responsible logistics so as to limit waste disposal or address recycling issues (e.g. Rogers \& Tibben-Lembke, 2001). Finally, the importance of environment could depend on the sector where companies operate as each one faces different challenges, needs and priorities (Fafaliou et al., 2006). For this reason, this study focuses on food and beverage companies.

Dixon-Fowler et al. (2017) stated that there is an academic research gap how the board of directors affects the corporate environmental performance regarding that should be investigated. Thus, the aim of this study is to investigate sig- 
nificant corporate governance characteristics that determine the environmental performance of companies that operate on food and beverage sector. In particular, three main variables are employed, namely the size of $\mathrm{BoD}$, the Board Independence and the presence of women on BoD. As far as environmental performance is concerned, Thomson Reuters DataStream provides non-financial data for listed companies. For the purpose of the study Environmental performance Score (EPS) is employed as a proxy of environmental performance in order to surpass subjectivity concerns of measuring environmental performance. Regarding the sample of study, companies that are listed on Food \& Beverages Price Return Index are employed in the proposed model for the year 2017. The study provides significant implications to major corporate stakeholders such as managers, shareholders and investors.

The rest of the paper is structured as follows: Section 2 discusses the role of $\mathrm{BoD}$ and presents the hypotheses development and Section 3 describes the employed methodology. Section 4 outlines the results of the study along with discussion of the results. The last section of the study presents the conclusions along with recommendation for future research.

\section{Literature Review}

\subsection{Board of Directors}

BoD is the mean by which a company protects not only the shareholders' interest but stakeholder interest as well (Pérez Carrillo et al., 2007; Quattrociocchi et al., 2019). BoD's main responsibility is to serve the link between shareholders and corporate managers and its supervisory capacity is determined by the size of BoD and the board composition (Villanueva-Villar et al., 2016).

BoD plays a vital role for the decision-making process regarding environmental initiatives. For instance, companies that intend to address environmental concerns such as decreased natural resources, increased pressure from environmental regulators, socially responsible investors, and other environmental bodies may create an environmental committee in order to formulate the appropriate environmental behavior and strategy (Kassinis \& Vafeas, 2002; Dixon-Fowler et al., 2017). In the field of non-financial disclosure, a number of studies investigated the role of corporate governance on environmental reporting by incorporating the role of BoD (e.g. Liao et al.; 2015; Tauringana \& Chithambo, 2015; Ezhilarasi \& Kabra, 2017).

Three main theories can be elaborated in relation to Corporate Governance and BoD. The first theory is Agency theory which explains the relationship between principals/owners and managers/agents, in our case the BoD. It is assumed that there is an information asymmetry between the aforementioned parties and the limited access to ascertain whether managers act with opportunistic behaviors (Adams, 1994; Jensen \& Meckling, 1976). A second theory related to Corporate Governance and BoD is Stewardship theory with roots in sociology and psychology (Al Mamun et al., 2013). Stewardship theory assumes that di- 
rectors act as good steward of the corporate asset making those decisions that are in the best interest of company (Donaldson \& Davis, 1991). In the environmental field, this theory supports that directors are probably more concerned about environmental performance as they perceive better how the environmental performance level influences perceptions of their own performance and reputation (Dixon-Fowler et al., 2017; Fama, 1980). Resource dependence theory is another theory that is connected with BoD. According to Al Mamun et al. (2013), each company has a lot of reasons and motives to elaborate relationships with other companies or external bodies in order to reduce environmental uncertainties. Directors of Boards are responsible to develop and enhance such a type of relationships with other companies and bodies so as to bring additional environmental knowledge and resources needed to elaborated environmental initiatives (Dalton et al., 1999; Goodstein et al., 1994).

Even if the increased interest of academic community about the role of BoD on CSR, less is known regarding the effects of $\mathrm{BoD}$ characteristics on environmental performance of companies operating in Food and Beverage Sector.

\subsection{Hypotheses Development}

This section describes the hypotheses on the impact of BoD characteristics on the environmental performance. Three main hypotheses are under investigation based on the size of $\mathrm{BoD}$, the Board Independence and presence of women on $\mathrm{BoD}$. The following analysis concerns prior empirical studies regarding the proposed explanatory variables in relation not only to the environmental aspect but also from the broad concept of CSR and sustainability. A priori hypothesis development cannot be made as the results from the prior empirical studies are controversial (Reverte, 2009; Branco \& Rodrigues, 2008).

\subsubsection{Size of BoD}

The size of $\mathrm{BoD}$ is considered as a critical determinant of the board's ability to apply strategic actions. The size of $\mathrm{BoD}$ is an internal body that monitors the management's performance. A lot of directors in a Board may be a crucial problem for reaching consensus regarding specific decisions and, in addition, it can be a factor of decreased motivation and satisfaction because of limited participation (Shaw, 1981; Jewell \& Reitz, 1981). Jensen (1993) stated that a large BoD tends to serve more symbolic purposes interacting with society rather than with managerial processes. In addition, a smaller size BoD assists the Board to take unanimous decisions. For instance, Kassinis \& Vafeas (2002) based on 209 USA companies found empirically that large $\mathrm{BoD}$ are less effective in relation to environmental behavior increasing the likelihood of becoming an environmental lawsuit defendant. On the other hand, more members of BoD mean directors with diverge experience, studies and knowledge that could be very helpful to confront environmental concerns by providing environmental advice (de Villiers et al., 2011; Esa \& Ghazali, 2012). For instance, Liao et al. (2015) found that more directors in a Board seem that they act positively on moderating detri- 
mental environmental repercussions. However, prior empirical studies on the field of CSR found that a larger Board could intensify communication and coordination concerns among the members (e.g. Jensen, 1993; Eisenberg et al., 1998). Focused on CSR disclosure, Siregar and Yanivi (2010) found that the size of Board has a positive and concave relationship with corporate social disclosure index and corporate social disclosure length.

Thus, the following two hypotheses have been developed:

H1a: The size of BoD has a positive effect on environmental performance.

H1b: The relationship between the $\mathrm{BoD}$ and environmental performance is concave.

\subsubsection{Women Presence on BoD}

Gender diversity has been attracted the interest of various scientific fields such as psychology and management in order to analyze gender specific attitudes or behaviors (e.g. Bussey \& Bandura, 1999; Galbreath, 2018). Huse and Solberg (2006) investigated the role and the contribution of women on BoD. The results showed that women directors are wiser and more diligent than male ones. In addition, women directors contribute to the creation of a good atmosphere in the Board and support soft values. Similarly, Barako and Brown (2008) showed that women have a significant effect on corporate socially responsible behaviors increasing the possibility to confront more effectively the environmental concerns than men directors. Birindelli et al. (2019) focused on the bank sector found that companies form different geographical regions (Europe, Middle East and Africa) and that there is a nonlinear relationship between women directors on $\mathrm{BoD}$ and the environmental performance. Based on the United Kingdom companies, Liao et al. (2015) revealed that more women directors on BoD affect positively the environmental disclosure performance. Focused on Fortune 500 companies, Ciocirlan and Pettersson (2012) provided some explanations of women directors' orientation to climate change concerns. Firstly, women is more likely to estimate the environmental risks, to be compassionate and nurturing, while men seem to be more competitively oriented. However, there are studies that support that there is a low influence of women on BoD to corporate environmental initiatives (e.g. Glass \& Cook, 2018). Therefore, Alazzani et al. (2017) showed no association between women directors on Board and environmental performance taking into account Malaysian companies.

Thus, taking into account the aforementioned studies, the hypothesis is:

$\mathrm{H} 2$ : The presence of women on the board has a positive effect on the environmental performance

\subsubsection{Board Independence}

Liao et al. (2015) stated that higher levels of independent directors are a detrimental factor to monitor management monitoring effectively in order to mitigate agency problems (Fama \& Jensen, 1983). According to this, independent directors tend to be more objective and focus more on strategic issues and not to 
daily operation issues (Kesner \& Johnson, 1990; de Villiers et al., 2011). McKendall et al. (1999) supported that environmental investments is more possible to be realized by an independent BoD resisting to any pressure to detain or cancel similar investments. Prior empirical studies showed mixed results regarding the effect of Board independence on environmental performance. For instance, García Sánchez et al. (2018) showed that in banking Spanish companies higher levels of Board independence affect positively CSR behavior. Zahra (2001) stated that independent directors are more possible to consider social goals than inside directors. De Villiers et al. (2011) took into account a sample of more than 1.000 companies for the years 2003 and 2004 and showed that more independent directors on Board have a significant impact on environmental performance. However, a high level of Board independence seems not to have a significant effect. Moreover, Biswas et al. (2018) compromised Australian listed companies on Australian Securities Exchange for the period 2004-2015 and it is showed that board independence influences the environmental performance. However, Zou et al. (2015) took into account Chinese manufacturing companies and found that independent directors do not exert a significant influence on the environmental performance. Similarly, Berrone and Gomez-Mejia, (2009) and Allegrini and Greco (2013) did not find any relationship between board independence and sustainability disclosure performance. Thus, the underlying assumption is:

H3: Independent directors on Board have a positive effect on the environmental performance.

\section{Methodology}

\subsection{The Sample}

The sample considers only listed companies as large in size companies are more possible to integrate environmental initiatives than medium or small ones (Ghazali, 2007). As this study focuses on food and beverage companies, companies listed on Thomson Reuters Global Food \& Beverages Index were employed to examine the proposed hypotheses. Corporate data, both dependent and independent variable, were retrieved by Thomson Reuters' online platform database. In particular, Thomson Reuters DataStream incorporates a historical financial database with over 35 million individual instruments or indicators across all major asset classes by using a number of different information sources such as annual reports, corporate sustainability reports, nongovernmental organizations (Dyck et al., 2019). Thomson Reuters DataStream was selected because it is considered among the reliable research database and it is used by a number of academic research studies (e.g. Bamidele Oyedele, 2014; Akbas et al., 2018; Poza \& Mong, 2020).

In total, 174 out of 490 companies were considered due to missing data from the online data. A major explanation of missing data is that companies are not obligated to incorporate environmental initiatives and publish the non-financial information. 


\subsection{Dependent and Independent Variables}

This section describes both dependent and independent variables which are considered in the study. In general, there are different approaches to measure corporate environmental performance. The first approach takes into account single environmental measures such as greenhouse gas emissions (Luo \& Tang, 2014), hazardous waste produced in tones (Iatridis, 2013) toxics release inventory (Patten, 2002) ratio of toxic waste recycled to total toxic waste generated (Al-Tuwaijri et al., 2004). Another approach is the adoption of dummy variables as a proxy of environmental performance such as the conviction or not of environmental offence (Tauringana et al., 2017). The limitation of the above approaches is that it concerns only one dimension of environmental performance neglecting the wide range of environmental aspect. The second approach concerns an aggregate index similar to those that are proposed by KLD and Thomson Reuters' online database (e.g. Nazari et al., 2017; Dyck et al., 2019). In this study, Environmental Score provided by Thomson Reuters' online database is employed as a proxy for the environmental performance. In particular, corporate environmental performance data was obtained from Thomson Reuter Datastream for the year 2017. The environmental performance score ranges between 0 and 100 revealing the level of environmental performance.

As far as independent variables are concerned, three explanatory variables were employed in relationship to the environmental performance: the Board Size, the Board Independence and the Board gender composition. Regarding Board Size, this study took into account prior empirical studies by proposing as a definition the total number of board members at the end of the fiscal year. For the Board Independence the Percentage of independent board members is used as reported by the company, while for Board gender composition the Percentage of women on the board of directors is adopted. Two control variables are employed in the proposed model: firm size and financial leverage. Large in size companies tend to attract the interest of various stakeholders measured by market capitalization as a proxy for the company's size, while financial leverage is measured by the total debt divided by total assets as a proxy of creditors' power (Branco \& Rodrigues, 2008). Table 1 presents the definitions for both dependent and independent variables.

Multiple linear regression model is employed in order to predict the environmental performance from three corporate governance variables (e.g. Haniffa \& Cooke, 2005; Branco \& Rodrigues, 2008) using the statistical Stata software package. The form of the proposed model is:

$$
\mathrm{EP}=b_{0}+b_{1} * \mathrm{EP}+b_{2} * \mathrm{BoD}+b_{3} * \mathrm{BoD} 2+b_{4} * \mathrm{BI}+b_{5} * \mathrm{BGC}+b_{6} * \mathrm{CZ}+b_{7} * \mathrm{FV}
$$

where:

$$
\begin{aligned}
& \mathrm{EP}=\text { Environmental Performance } \\
& \mathrm{BoD}=\text { Board Size }
\end{aligned}
$$


Table 1. Definitions for both dependent and independent variables.

\begin{tabular}{cl}
\hline Variables & \multicolumn{1}{c}{ Definitions } \\
\hline The environmental pillar measures a company's impact on living \\
and non-living natural systems, including the air, land and water, \\
anvironmental & $\begin{array}{l}\text { as well as complete ecosystems. It reflects how well a company } \\
\text { Performance }\end{array}$ \\
& $\begin{array}{l}\text { capitalize on environmental opportunities in order to generate } \\
\text { long term shareholder value. }\end{array}$ \\
Board Size & The total number of board members at the end of the fiscal year \\
Board Independence & $\begin{array}{l}\text { Percentage of independent board members as reported } \\
\text { by the company }\end{array}$ \\
Board Gender Composition & Percentage of women on the board of directors. \\
Company Size & Market Capitalization \\
Financial Leverage & Total debt divided by total assets \\
\hline
\end{tabular}

$$
\begin{aligned}
& \text { BoD2 = Square of Board Size } \\
& \text { BI = Board Independence } \\
& \text { BGC = Board gender composition } \\
& \text { CZ = Company's Size } \\
& \text { FV = Financial Leverage }
\end{aligned}
$$

A number of statistical tests has been developed to assure the appropriateness of data for statistical analysis.

\section{Results}

\subsection{Descriptive Statistics and Correlations}

In total, the sample compromises companies that the headquarters derived from 31 countries. For instance, USA companies constitutes 57 companies representing $32.7 \%$ of the total sample, while companies operating their headquarters in Australia, United Kingdom and Japan represent $8.6 \%, 8 \%$ and $7.5 \%$, respectively, Table 2.

Table 3 presents the descriptive statistics of all variables employed in the proposed model. The results mainly concern environmental performance which means value reaches 63 out of 100 points, while the minimum value is 12.17 to 95.48. A possible explanation is that companies are not obligated to have environmental initiatives in their business operation beyond the requirements of law. In addition, companies probably are not willing to disseminate such initiatives because competitors are available to copy specific competitive advantages. Regarding the values of skewness and kurtosis, they are under acceptable ranges showing the normality distribution of variables.

Table 4 presents the correlation values among independent variables. The results show that there is no multicollinearity among explanatory variables. Based on Pearson's correlation coefficients, the maximum correlation value is 0.5108 which does not exceed the value 0.8 or 0.9 (Gujarati, 1988).

${ }^{1}$ The variable of Market Capitalization is converted in logarithm form in order to correct its skewness and kurtosis. 
Table 2. The sample's list.

\begin{tabular}{|c|c|c|}
\hline Country & Number & Percentage \\
\hline Switzerland & 4 & $2.3 \%$ \\
\hline Australia & 15 & $8.6 \%$ \\
\hline Belgium & 1 & $0.6 \%$ \\
\hline Canada & 3 & $1.7 \%$ \\
\hline Chile & 1 & $0.6 \%$ \\
\hline China & 7 & $4.0 \%$ \\
\hline Denmark & 2 & $1.1 \%$ \\
\hline France & 3 & $1.7 \%$ \\
\hline Germany & 1 & $0.6 \%$ \\
\hline China (Mainland) & 5 & $2.9 \%$ \\
\hline India & 5 & $2.9 \%$ \\
\hline Indonesia & 4 & $2.3 \%$ \\
\hline Ireland & 2 & $1.1 \%$ \\
\hline Japan & 13 & $7.5 \%$ \\
\hline South Korea & 1 & $0.6 \%$ \\
\hline Malaysia & 8 & $4.6 \%$ \\
\hline Netherlands & 1 & $0.6 \%$ \\
\hline Norway & 3 & $1.7 \%$ \\
\hline New Zealand & 4 & $2.3 \%$ \\
\hline Philippines & 1 & $0.6 \%$ \\
\hline Ukraine & 1 & $0.6 \%$ \\
\hline South Africa & 6 & $3.4 \%$ \\
\hline Saudi Arabia & 1 & $0.6 \%$ \\
\hline Singapore & 4 & $2.3 \%$ \\
\hline Spain & 1 & $0.6 \%$ \\
\hline Sweden & 1 & $0.6 \%$ \\
\hline Thailand & 2 & $1.1 \%$ \\
\hline Turkey & 2 & $1.1 \%$ \\
\hline Taiwan & 1 & $0.6 \%$ \\
\hline United Kingdom & 14 & $8.0 \%$ \\
\hline USA & 57 & $32.8 \%$ \\
\hline Total & 174 & $100 \%$ \\
\hline
\end{tabular}

Table 3. Descriptive statistics.

\begin{tabular}{ccccccc}
\hline Variables & Mean & Min & Max & Std. Dev. & Skewness & Kurtosis \\
\hline EP & 63.14494 & 12.97 & 95.48 & 29.18641 & -0.5404878 & 1.77154 \\
BoD & 9.770115 & 3 & 20 & 2.927648 & 0.534294507 & 0.490940029 \\
BI & 45.55874 & 0.67 & 94.18 & 29.2278 & -1.447035418 & 0.043721018 \\
BGC & 17.10379 & 0 & 75 & 13.5355 & 0.995029191 & 0.745605627 \\
CZ & 7.238512 & 5.553081 & 11.20747 & 1.123159 & 1.378287546 & 1.024557403 \\
FV & 0.2471049 & 0.0290142 & 0.7205555 & 0.1238822 & 2.234998534 & 1.155419996
\end{tabular}


Table 4. Correlation matrix.

\begin{tabular}{ccccccc}
\hline Variables & EP & BoD & BI & BGC & FV & CZ \\
\hline EP & 1 & & & & & \\
BoD & $0.5108^{*}$ & 1 & & & & \\
BI & -0.0763 & 0.0122 & 1 & & & \\
BGC & $0.2157^{*}$ & $0.2368^{*}$ & $0.3186^{*}$ & 1 & & \\
FV & 0.1044 & -0.0490 & $-0.2730^{*}$ & -0.0740 & 1 & 1 \\
CZ & $0.4454^{*}$ & $0.1998^{*}$ & $-0.2356^{*}$ & -0.0515 & 0.0853 & 1 \\
\hline
\end{tabular}

\subsection{Regression Findings and Discussion}

Regarding the proposed model, the heteroscedasticity concerns according to the White's test were dealt by heteroskedasticity-robust standard errors ${ }^{2}$. Based on Skweness test of normality, the results showed that residuals are normally distributed $(p=0.1433>0.10)$. Furthermore, testing for omitted variables, the Ramsey RESET test revealed that there is no need for more variables $(p=$ $0.3898>0.1)$. The proposed model is significant with $\mathrm{R}$-square $=0.4391$ and $\mathrm{F}$ value $=25.11(p<0.01)$; thus, $43.91 \%$ of the variation of EP score is explained by explanatory variables, Table 5 .

Regarding independent variables, the number of $\mathrm{BoD}$ members and the percentage of women on Board are significantly positive at $1 \%$, the square of $\mathrm{BoD}$ is significantly negative at $1 \%$, while the percentage of independent directors is statistically insignificant. The coefficient of market capitalization is positive and statistically significant at $1 \%$, whilst the financial leverage is not statistically significant.

Extending the above results, the size of BoD tends to contribute significantly to environmental performance. This is owned to the fact that companies with larger board of directors are more likely to possess the diversity and richness of environmental expertise so as to succeed higher levels of environmental performance (de Villiers et al., 2011). Based on agency theory, more directors on BoD means that the directors act more effectively in terms of environmental performance decreasing the monitor cost of the shareholder. It is implied that the large size of BoD satisfies not only shareholders' interest by improving the monitoring process but also stakeholders relative to natural environment (Hillman \& Dalziel, 2003). Regarding resource dependency theory, larger BoD is likely to have better access to financial resources because of enhanced ability to create synergies that could be deployed in environmental activities achieving better environmental performance (Dalton et al., 1999; Goodstein et al., 1994). The results are inconsistent with the point of view that supports that more directors in Board face more difficulties in strategic decision-making which CEO appoints difficulties in controlling process of the board (Jensen, 1993). However, the results revealed that the BoD's size has a positive and concave relationship with the ${ }^{2}$ The used of robust option was added at the end of the regression command. 
Table 5. Results of the regression analysis.

\begin{tabular}{cccc}
\hline Variables & Coefficient & Robust std. err. & t-statistic \\
\hline BZ & $11.97771^{*}$ & 2.939364 & 4.07 \\
BZ2 & $-0.376415^{*}$ & 0.1224432 & -3.07 \\
BI & -0.0483407 & 0.0672364 & -0.72 \\
BGC & $0.3245394^{*}$ & 0.1221481 & 2.66 \\
FV & 19.23324 & 13.23367 & 1.45 \\
CZ & $9.069783^{*}$ & 1.809191 & 5.01 \\
con & $-88.49306^{*}$ & 16.15131 & -5.48 \\
R-squared & 0.4391 & & \\
F value & $25.11^{*}$ & & \\
\hline
\end{tabular}

${ }^{*}$ Significant at 0.01 (two-tailed).

environmental performance consistent with Siregar and Bachtiar (2010). It is implied that more directors on board creates more coordination concerns making the monitoring and decision process ineffective leading to lower levels of environmental performance and, under the Agency theory, increasing the cost of monitoring by the principals/owners of food companies.

As far as BGC is concerned, the results reveal that more women on BoD has a positive effect on environmental performance. It is implied that women directors on BoD have positive attitude towards environmental concerns than men because they perceive better the environmental risks (Diamantopoulos et al., 2003; Hur et al., 2016). Thus, it can be stated that the presence of more women directors on BoD seem to have an ethical stance towards the environmental aspect. This result of the study is inconsistent with Alazzani et al. (2017), Glass et al. (2016) and Fakoya and Nakeng (2019).

Even if independent directors on Board are significant for companies, the results showed that the increased percentage of independent directors has no impact on environmental performance consistent with Allegrini and Greco (2013). The insignificant effect of independent directors is probably owned to different educational backgrounds and professional experience.

Among the company's characteristics, the company's size and financial leverage have a positive effect on environmental performance. Larger companies were found that they consider more the environmental issues and concerns, probably, because they can afford the economic cost so as to satisfy the stakeholders' expectation in relation to natural environment (e.g. Ezhilarasi and Kabra, 2017). In addition, the creditor's power seems to affect positively the environmental performance revealing the corporate management can expand their corporate initiatives beyond the traditional operations.

The findings of the study contribute to understand which BoD characteristics are determinants of increased environmental performance in the context of food and beverage sector. 
The results of the study have practical implications to different stakeholders. For instance, the socially responsible investors could identify specific characteristics of BoD that confirm the intention of some companies for higher level environmental performance. In this way, investors are able to detect which $\mathrm{BoD}$ takes into account environmental concerns. In addition, corporate management is able to send a sophisticated signal to external stakeholders indicating that company, the potential for improved environmental performance. The results is a topic of increased interest by global policy makers or regulators for corporate governance that aims to increase the effectiveness of $\mathrm{BoD}$, via the size of $\mathrm{BoD}$ and the percentage of independent directors, towards CSR and, in particular, towards environmental policy. Finally, shareholders are able to improve corporate environmental performance by introducing to the Board specific characteristics not only to ensure higher levels of environmental performance but also to minimize the monitor cost of corporate management.

\section{Conclusion}

Since environmental concerns are crucial for companies, the study intends to investigate the role of corporate governance characteristics on corporate environmental performance. In particular, three main aspects of BoD are employed, namely, the size of $\mathrm{BoD}$, the Board Independence and the Board gender composition in order to ascertain their significance on the environmental performance.

The contribution of this study to the existing literature is summarized as follows: To our knowledge, the study focused, for the first time, on companies operating in food and beverage sector by investigating how the BoD characteristics affect the corporate environmental performance. Secondly, the environmental performance score as calculated by Thomson Reuters has not been employed extensively in the prior empirical studies. This composite index was employed in order to cover the wide range of environmental aspects of CSR avoiding subjectivity concerns.

The results reveal that the increased size of $\mathrm{BoD}$ and independent directors are vital factors of environmental concerns. However, a larger BoD leads to lower levels of environmental performance.

The findings of the study have important implications for different stakeholders such as socially responsible investors that intend to identify companies that consider in their business operation environmental concerns. Furthermore, shareholders and managers may propose specific corporate governance characteristics, while regulators could recommend in their corporate governance codes specific attributes related to increased environmental performance.

The core innovation of this study is the research of how corporate governance characteristics affect the environmental performance of food and beverage companies as limited attention that has been paid in this sector. In addition, the employment of Environmental Score as calculated by Thomson Reuters DataStream as a proxy of environmental performance is considered as a novel. 
This study presents some limitations. First of all, the data that are employed in the study concern only one year of study. Future studies may incorporate more data for a period of years in order to assure that the results are confirmed. Furthermore, future empirical studies could compare the present results with other companies that operate in service or manufacturing sectors in order to ascertain similarities or differences among them. Finally, even if CSR initiatives basically concern large in size companies, future studies should incorporate in their sample not only listed companies on stock index but also medium or small companies in order to examine different or similar corporate governance behaviors.

\section{Conflicts of Interest}

The authors declare no conflicts of interest regarding the publication of this paper.

\section{References}

Adams, M. B. (1994). Agency Theory and the Internal Audit. Managerial Auditing Journal, 9, 8-12. https://doi.org/10.1108/02686909410071133

Akbas, F., Markov, S., Subasi, M., \& Weisbrod, E. (2018). Determinants and Consequences of Information Processing Delay: Evidence from the Thomson Reuters Institutional Brokers' Estimate System. Journal of Financial Economics, 127, 366-388. https://doi.org/10.1016/j.jfineco.2017.11.005

Al Mamun, A., Yasser, Q. R., \& Rahman, M. A. (2013). A Discussion of the Suitability of Only One vs. More than One Theory for Depicting Corporate Governance. Modern Economy, 4, 37-48. https://doi.org/10.4236/me.2013.41005

Alanazi, A. S. (2019). Corporate Governance and the Characteristics of the Board of Directors: Evidence from an Emerging Market. Corporate Board: Role, Duties \& Composition, 15, 17-34. https://doi.org/10.22495/cbv15ilart2

Alazzani, A., Hassanein, A., \& Aljanadi, Y. (2017). Impact of Gender Diversity on Social and Environmental Performance: Evidence from Malaysia. Corporate Governance (Bingley), 17, 266-283. https://doi.org/10.1108/CG-12-2015-0161

Allegrini, M., \& Greco, G. (2013). Corporate Boards, Audit Committees and Voluntary Disclosure: Evidence from Italian Listed Companies. Journal of Management \& Governance, 17, 187-216. https://doi.org/10.1007/s10997-011-9168-3

Al-Tuwaijri, S. A., Christensen, T. E., \& Hughes II, K. E. (2004). The Relations among Environmental Disclosure, Environmental Performance, and Economic Performance: A Simultaneous Equations Approach. Accounting, Organization and Society, 29, 447-471. https://doi.org/10.1016/S0361-3682(03)00032-1

Arlow, P., \& Gannon, M. J. (1982). Social Responsiveness, Corporate Structure and Economic Performance. Academy of Management Review, 7, 235-241. https://doi.org/10.5465/amr.1982.4285580

Bamidele Oyedele, J. (2014). Performance and Significance of UK-Listed Infrastructure in a Mixed-Asset Portfolio. Journal of European Real Estate Research, 7, 199-215. https://doi.org/10.1108/JERER-08-2013-0015

Barako, D. G., \& Brown, A. M. (2008). Corporate Social Reporting and Board Representation: Evidence from the Kenyan Banking Sector. Journal of Management and Governance, 12, 309-324. https://doi.org/10.1007/s10997-008-9053-x 
Birindelli, G., Iannuzzi, A. P., \& Savioli, M. (2019). The Impact of Women Leaders on Environmental Performance: Evidence on Gender Diversity in Banks. Corporate Social Responsibility and Environmental Management, 26, 1485-1499. https://doi.org/10.1002/csr.1762

Biswas, P. K., Mansi, M., \& Pandey, R. (2018). Board Composition, Sustainability Committee and Corporate Social and Environmental Performance in Australia. Pacific Accounting Review, 30, 517-540. https://doi.org/10.1108/PAR-12-2017-0107

Branco, M. C., \& Rodrigues, L. L. (2008). Factors Influencing Social Responsibility Disclosure by Portuguese Companies. Journal of Business Ethics, 83, 685-701. https://doi.org/10.1007/s10551-007-9658-Z

Bussey, K., \& Bandura, A. (1999). Social Cognitive Theory of Gender Development and Differentiation. Psychological Review, 106, 676-713.

https://doi.org/10.1037/0033-295X.106.4.676

Campbell (2007). Why Would Corporations Behave in Socially Responsible Ways? An Institutional Theory of Corporate Social Responsibility. Academy of Management Review, 32, 946-967. https://doi.org/10.5465/amr.2007.25275684

Ciocirlan, C., \& Pettersson, C. (2012). Does Workforce Diversity Matter in the Fight against Climate Change? An Analysis of Fortune 500 Companies. Corporate Social Responsibility and Environmental Management, 19, 47-62.

https://doi.org/10.1002/csr.279

Clarkson, P. M., Overell, M. B., \& Chapple, L. (2011). Environmental Reporting and Its Relation to Corporate Environmental Performance. Abacus, 47, 27-60. https://doi.org/10.1111/j.1467-6281.2011.00330.x

Commission of European Communities (2001). Green Paper: Promoting a European Framework for Corporate Social Responsibility. Brussels.

Dalton, D. R., Daily, C. M., Johnson, J. L., \& Ellstrand, A. E. (1999). Number of Directors and Financial Performance: A Meta-Analysis. Academy of Management Journal, 42, 674-686. https://doi.org/10.2307/256988

de Villiers, C., Naiker, V., \& van Staden, C. J. (2011). The Effect of Board Characteristics on Firm Environmental Performance. Journal of Management, 37, 1636-1663. https://doi.org/10.1177/0149206311411506

Diamantopoulos, A., Schlegelmilch, B. B., Sinkovics, R. R., \& Bohlen, G. M. (2003). Can Socio-Demographics Still Play a Role in Profiling Green Consumers? A Review of the Evidence and an Empirical Investigation. Journal of Business Research, 56, 465-480. https://doi.org/10.1016/S0148-2963(01)00241-7

Dixon-Fowler, H. R., Ellstrand, A. E., \& Johnson, J. L. (2017). The Role of Board Environmental Committees in Corporate Environmental Performance. Journal of Business Ethics, 140, 423-438. https://doi.org/10.1007/s10551-015-2664-7

Donaldson, L., \& Davis, J. H. (1991). Stewardship Theory or Agency Theory: CEO Governance and Shareholder Returns. Australian Journal of Management, 16, 49-65. https://doi.org/10.1177/031289629101600103

Dyck, A., Lins, K. V., Roth, L., \& Wagner, H. F. (2019). Do Institutional Investors Drive Corporate Social Responsibility? International Evidence. Journal of Financial Economics, 131, 693-714. https://doi.org/10.1016/j.jfineco.2018.08.013

Eisenberg, T., Sundgren, S., \& Wells, M. (1998). Larger Board Size and Decreasing Firm Value in Small Firms. Journal of Financial Economics, 48, 35-54.

https://doi.org/10.1016/S0304-405X(98)00003-8 
Esa, E., \& Ghazali, N. A. M. (2012). Corporate Social Responsibility and Corporate Governance in Malaysian Government-Linked Companies. Corporate Governance (Bingley), 12, 292-305. https://doi.org/10.1108/14720701211234564

Ezhilarasi, G., \& Kabra, K. C. (2017). The Impact of Corporate Governance Attributes on Environmental Disclosures: Evidence from India. Indian Journal of Corporate Governance, 10, 24-43. https://doi.org/10.1177/0974686217701464

Fafaliou, I., Lekakou, M., \& Theotokas, I. (2006). Is the European Shipping Industry Aware of the Corporate Social Responsibility? The Case of the Greek-Owned Short Sea Shipping Companies. Marine Policy, 30, 412-419. https://doi.org/10.1016/j.marpol.2005.03.003

Fakoya, M. B., \& Nakeng, M. V. (2019). Board Characteristics and Sustainable Energy Performance of Selected Companies in South Africa. Sustainable Production and Consumption, 18, 190-199. https://doi.org/10.1016/j.spc.2019.02.003

Fama, E. F. (1980). Agency Problems and the Theory of the Firm. The Journal of Political Economy, 88, 288-307. https://doi.org/10.1086/260866

Fama, E. F., \& Jensen, M. C. (1983). Separation of Ownership and Control. Journal of Law and Economics, 26, 301-325. https://doi.org/10.1086/467037

Galbreath, J. (2018). Is Board Gender Diversity Linked to Financial Performance? The Mediating Mechanism of CSR. Business \& Society, 57, 863-889. https://doi.org/10.1177/0007650316647967

Galvão, A., Mendes, L., Marques, C., \& Mascarenhas, C. (2019). Factors Influencing Students' Corporate Social Responsibility Orientation in Higher Education. Journal of Cleaner Production, 215, 290-304. https://doi.org/10.1016/j.jclepro.2019.01.059

García-Sánchez, I. M., Martínez-Ferrero, J., \& García-Meca, E. (2018). Board of Directors and CSR in Banking: The Moderating Role of Bank Regulation and Investor Protection Strength. Australian Accounting Review, 28, 428-445.

https://doi.org/10.1111/auar.12199

Ghazali, N. A. M. (2007). Ownership Structure and Corporate Social Responsibility Disclosure: Some Malaysian Evidence. Corporate Governance, 7, 251-266. https://doi.org/10.1108/14720700710756535

Glass, C., \& Cook, A. (2018). Do Women Leaders Promote Positive Change? Analyzing the Effect of Gender on Business Practices and Diversity Initiatives. Human Resource Management, 57, 823-837. https://doi.org/10.1002/hrm.21838

Glass, C., Cook, A., \& Ingersoll, A. R. (2016). Do Women Leaders Promote Sustainability? Analysing the Effect of Corporate Governance Composition on Environmental Performance. Business Strategy and the Environment, 25, 495-511. https://doi.org/10.1002/bse.1879

Goodstein, J., Gautam, K., \& Boeker, W. (1994). The Effect of Board Size and Diversity on Strategic Change. Strategic Management Journal, 15, 241-250.

https://doi.org/10.1002/smj.4250150305

Gujarati, D. N. (1988). Basic Econometrics, International Edition. New York: McGraw-Hill.

Haniffa, R. M., \& Cooke, T. E. (2005). The Impact of Culture and Governance on Corporate Social Reporting. Journal of Accounting and Public Policy, 24, 391-430.

https://doi.org/10.1016/j.jaccpubpol.2005.06.001

Hartmann, M. (2011). Corporate Social Responsibility in the Food Sector. European Review of Agricultural Economics, 38, 297-324. https://doi.org/10.1093/erae/jbr031

Hillman, A. J., \& Dalziel, T. (2003). Boards of Directors and Firm Performance: Integrat- 
ing Agency and Resource Dependence Perspectives. Academy of Management Review, 28, 383-396. https://doi.org/10.5465/amr.2003.10196729

Hur, W. M., Kim, H., \& Jang, J. H. (2016). The Role of Gender Differences in the Impact of CSR Perceptions on Corporate Marketing Outcomes. Corporate Social Responsibility and Environmental Management, 23, 345-357. https://doi.org/10.1002/csr.1380

Huse, M., \& Solberg, A. G. (2006). Gender-Related Boardroom Dynamics: How Scandinavian Women Make and Can Make Contributions on Corporate Boards. Women in Management Review, 21, 113-130. https://doi.org/10.1108/09649420610650693

Iatridis, G. E. (2013). Environmental Disclosure Quality: Evidence on Environmental Performance, Corporate Governance and Value Relevance. Emerging Markets Review, 14, 55-75. https://doi.org/10.1016/j.ememar.2012.11.003

Jamali, D. (2008). A Stakeholder Approach to CSR: A Fresh Perspective into Theory and Practice. Journal of Business Ethics, 82, 213-231. https://doi.org/10.1007/s10551-007-9572-4

Jensen, M. (1993). The Modern Industrial Revolution, Exit, and the Failure of Internal Control Systems. Journal of Finance, 48, 831-880.

https://doi.org/10.1111/j.1540-6261.1993.tb04022.x

Jensen, M. C., \& Meckling, W. H. (1976). Theory of the Firm: Managerial Behavior, Agency Costs and Ownership Structure. Journal of Financial Economics, 3, 305-360. https://doi.org/10.1016/0304-405X(76)90026-X

Jewell, L. N., \& Reitz, H. J. (1981). Group Effectiveness in Organizations. Glenview, IL: Scott-Foreman.

Jones, P., Comfort, D., Hillier, D., \& Eastwood, I. (2005). Corporate Social Responsibility: A Case Study of the UK's Leading Food Retailers. British Food Journal, 107, 423-435. https://doi.org/10.1108/00070700510602192

Kassinis, G., \& Vafeas, N. (2002). Corporate Boards and Outside Stakeholders as Determinants of Environmental Litigation. Strategic Management Journal, 23, 399-415. https://doi.org/10.1002/smj.230

Kesner, I. F., \& Johnson, R. B. (1990). An Investigation of the Relationship between Board Composition and Stockholder Suits. Strategic Management Journal, 11, 327-336. https://doi.org/10.1002/smj.4250110408

Kitchin, T. (2002). Corporate Social Responsibility: A Brand Explanation. Brand Management, 10, 312-326. https://doi.org/10.1057/palgrave.bm.2540127

Liao, L., Luo, L., \& Tang, Q. (2015). Gender Diversity, Board Independence, Environmental Committee and Greenhouse Gas Disclosure. The British Accounting Review, 47, 409-424. https://doi.org/10.1016/j.bar.2014.01.002

Luo, L., \& Tang, Q. (2014). Does Voluntary Carbon Disclosure Reflect Underlying Carbon Performance. Journal of Contemporary Accounting \& Economics, 10, 191-205. https://doi.org/10.1016/j.jcae.2014.08.003

McKendall, M., Sánchez, C., \& Sicilian, P. (1999). Corporate Governance and Corporate Illegality: The Effects of Board Structure on Environmental Violations. International Journal of Organizational Analysis, 7, 201-223. https://doi.org/10.1108/eb028900

Naciti, V. (2019). Corporate Governance and Board of Directors: The Effect of a Board Composition on Firm Sustainability Performance. Journal of Cleaner Production, 237, Article ID: 117727. https://doi.org/10.1016/j.jclepro.2019.117727

Nazari, J. A., Hrazdil, K., \& Mahmoudian, F. (2017). Assessing Social and Environmental Performance through Narrative Complexity in CSR Report. Journal of Contemporary 
Accounting \& Economics, 13, 166-178. https://doi.org/10.1016/j.jcae.2017.05.002

Organisation for Economic Co-Operation and Development (2004). Principles of Corporate Governance. Paris: OECD.

Patten, D. M. (2002). The Relation between Environmental Performance and Environmental Disclosure: A Research Note. Accounting Organizations and Society, 27, 763-773. https://doi.org/10.1016/S0361-3682(02)00028-4

Pérez Carrillo, E. F. (2007). Corporate Governance: Shareholders' Interests' and Other Stakeholders' Interests. Corporate Ownership \& Control, 4, 96-102. https://doi.org/10.2139/ssrn.2302532

Poza, C., \& Mong, M. (2020). A Real Time Leading Economic Indicator Based on Text Mining for the Spanish Economy. Fractional Cointegration VAR and Continuous Wavelet Transform Analysis. International Economics. https://doi.org/10.1016/j.inteco.2020.02.002

Quattrociocchi, B., Mercuri, F., \& Sergiacomi, S. (2019). The Link between CSR and the Board's Role: A Theoretical Framework on Non-Financial Disclosure. In New Challenges in Corporate Governance: Theory and Practice (pp. 435-448). Naples. https://doi.org/10.22495/ncpr 52

Reverte, C. (2009). Determinants of Corporate Social Responsibility Disclosure Ratings by Spanish Listed Firms. Journal of Business Ethics, 88, 351-366. https://doi.org/10.1007/s10551-008-9968-9

Roberts, S. (2003). Supply Chain Specific? Understanding the Patchy Success of Ethical Sourcing Initiatives. Journal of Business Ethics, 44, 159-170.

https://doi.org/10.1023/A:1023395631811

Rogers, D. S., \& Tibben-Lembke, R. (2001). An Examination of Reverse Logistics Practices. Journal of Business Logistics, 22, 129-148. https://doi.org/10.1002/j.2158-1592.2001.tb00007.x

Shaw, M. E. (1981). Group Dynamics: The Psychology of Small Group Behavior. New York: McGraw-Hill.

Siregar, V. S., \& Bachtiar, Y. (2010). Corporate Social Reporting: Empirical Evidence from Indonesia Stock Exchange. International Journal of Islamic and Middle Eastern Finance and Management, 3, 241-252. https://doi.org/10.1108/17538391011072435

Tauringana, V., \& Chithambo, L. (2015). The Effect of DEFRA Guidance on Greenhouse Gas Disclosure. British Accounting Review, 47, 425-444. https://doi.org/10.1016/j.bar.2014.07.002

Villanueva-Villar, M., Rivo-López, E., \& Lago-Peñas, S. (2016). On the Relationship between Corporate Governance and Value Creation in an Economic Crisis: Empirical Evidence for the Spanish Case. BRQ Business Research Quarterly, 19, 233-245. https://doi.org/10.1016/j.brq.2016.06.002

Wajeeh, I. A., \& Muneeza, A. (2012). Strategic Corporate Governance for Sustainable Mutual Development. International Journal of Law and Management, 54, 197-208. https://doi.org/10.1108/17542431211228593

Wei, W., Kim, G., Miao, L., Bhnke, C., \& Almanza, B. (2018). Consumer Inferences of Corporate Social Responsibility (CSR) Claims on Packaged Foods. Journal of Business Research, 83, 186-201. https://doi.org/10.1016/j.jbusres.2017.10.046

Zou, H. L., Zeng, S. X., Xie, L. N., \& Zeng, R. C. (2015). Are Top Executives Rewarded for Environmental Performance? The Role of the Board of Directors in the Context of China. Human and Ecological Risk Assessment, 21, 1542-1565. 
https://doi.org/10.1080/10807039.2014.958943

Berrone, P., \& Gomez-Mejia, L. R. (2009). Environmental Performance and Executive Compensation: An Integrated Agency-Institutional Perspective. Academy of Management Journal, 52, 103-126. https://doi.org/10.5465/amj.2009.36461950 